\title{
Breves comentários sobre algumas obras publicadas em 2017/2018
}

FERNÁNDEZ, Victor Ramiro. La trilogía del erizo-zorro: redes globales, trayectorias nacionales y dinámicas regionales desde la periferia. Barcelona: Anthropos Editorial; Santa Fe: Ediciones UNL, 2017.

Este é o mais importante livro sobre desenvolvimento regional publicado na América Latina nos últimos dez anos. E o é pela simples razão de, sem tergiversar, ir ao ponto: pensar desenvolvimento regional - mesmo dialogando com enfoques do centro - a partir da própria América Latina. O que o investigador Victor Ramiro Fernández faz de extraordinário nesta obra (que logo se tornará referência obrigatória para o estudo crítico do desenvolvimento regional no subcontinente) é, precisamente, colocar em xeque os enfoques convencionais oriundos da academia e dos centros de pensamento dos EEUU e da Europa. Tais enfoques tem tido a pretensão de universalidade, quando, de fato, partem das realidades de seus "países desenvolvidos". A periferia, inclusa aí a América Latina, tem consumido de forma passiva essas teorias, delas derivando políticas que vão sendo aplicadas sem critério às suas próprias realidades econômicas, políticas e socioculturais. A sua leitura é indispensável!

DANTAS, Aldo; ARROYO, Mónica; CATAIA, Márcio (org.) Dos circuitos da economia urbana aos circuitos espaciais de produção: um diálogo com a teoria de Milton Santos. Natal: Sebo Vermelho, 2017.

Esta coletânea, dedicada aos "professores" Milton Santos e Antonio Carlos Robert de Moraes, reúne, em suas mais de 550 páginas, 20 artigos de conhecidos geógrafos brasileiros. Os primeiros cinco estão abrigados na parte inicial, dedicada a "uma discussão sobre os conceitos". A segunda parte da coletânea, "circuitos espaciais de produção e dinâmicas atuais no uso do território brasileiro", é constituída por outros oito artigos. Os demais sete integram, por fim, a terceira parte: "circuitos da economia urbana e suas feições contemporâneas em cidades brasileiras". O que pretende unir as duas dezenas de textos que compõem esta coletânea, como se pode ler na "Introdução", é o propósito de "aproximar duas propostas teórico-conceituais desenvolvidas por Milton Santos, que dialogam e se complementam: os circuitos da economia urbana e os circuitos espaciais de producão e círculos de cooperação no espaço". Trata-se, sem dúvida, de importante referência para os estudos sobre a obra de Milton Santos.

D’ottaviano, Camila; ROVATI, João (org.). Para além da sala de aula: extensão universitária e planejamento urbano e regional. São Paulo: FAU/USP; ANPUR, 2017.

Este pequeno livro (por caber em menos de 150 páginas), organizado por Camila D'Ottaviano (USP) e João Rovati (UFRGS) é, antes de mais nada, um belo registro de um verdadeiro evento: a entrada em cena da "extensão" nas reuniões da Associação Nacional de Pós-Graduação e Pesquisa em Planejamento Urbano e Regional-ANPUR. O súbito despertar ocorreu em maio de 2016, durante o VIII SEPEPUR, que teve lugar em Porto Alegre/RS. Mas, foi durante o XVII ENANPUR, ocorrido em maio de 2017, na cidade de São Paulo/SP, que a extensão pode, ineditamente, dispor de uma "sessão temática" exclusiva. Dividido em três partes, pelas quais se distribuem sete textos e um posfácio, este pequeno livro constitui, como dito, um belo registro de um animado debate que desvelou, tanto para leigos quanto, sobretudo, para os estudiosos do 
planejamento urbano e regional, os - até então desconhecidos - "territórios da extensão universitária”. Recomenda-se sua leitura!

LANDA, Roger (Coordinador); ALVARADO, David; REVERÓN, Manuel Azuaje (Editores). El vuelo del Fénix: el capital - lecturas críticas a 150 años de su publicación (1867-2017). Buenos Aires: CLACSO, 2018.

Esta preciosa coletânea, dedicada a Itsván Mészáros e François Houtart, publicada em coedição pelo Conselho Latino Americano de Ciências Sociais-CLACSO e a Rede de Intelectuais e Artistas em Defesa da Humanidade, tem sua motivação na comemoração dos 150 anos da publicação da opus magna de Karl Marx. Por suas 450 páginas desfilam 17 importantes estudiosos - aí se encontrando, entre outros/as, Pablo González Casanova, Itsván Mészáros, Enrique Dussel, Franz Hinkelammert e Marta Harnecker - que se debruçam sobre aspectos econômicos, políticos e éticos de $O$ capital como, também, sobre as possibilidades de sua leitura desde a América Latina e a África. Entretanto, a maior parte dos textos se concentra mesmo sobre a atualidade de uma obra que, afinal, foi publicada em 1867. A coletânea rende uma bela homenagem a uma referência fundamental para se entender o mundo em que vivemos. Um mundo que, aliás, se parece cada vez mais com aquele de meados do século XIX.

ROEDEL, Tamily (org.). Proteção ao meio ambiente: aspectos legais, iniciativas empresariais, ações de educação ambiental. Joinville: Manuscritos Editora., 2018.

Proteção ao meio ambiente é uma coletânea que reúne 16 contribuições originais, redigidas por 34 diferentes autoras/es. Distribuídos em quatro seções distintas, os artigos parte, em sua maioria, de uma perspectiva jurídica da problemática ambiental. Outros, porém, adotam enfoques diversos, como os da economia ecológica e da educação ambiental. Os artigos são, majoritariamente, estudos sobre questões concretas, isto é, têm um viés destacadamente empírico. Os assuntos abarcados vão desde a mudança ambiental global, passando por problemas como desastres socioambientais e conflitos entre o agronegócio e assentamentos rurais, até questões mais específicas de legislação ambiental. A relevância desta coletânea está, pois, na oferta de um leque bastante amplo de textos bem escritos sobre temáticas e desde abordagens que têm como pano de fundo a proteção ambiental em escala global, nacional e regional/local. Destaque-se o cuidado da editora com o belo acabamento gráfico em papel reciclado. 